\title{
REALITAS PENGELOLAAN PIUTANG PAJAK BUMI DAN BANGUNAN PERDESAAN DAN PERKOTAAN DI KABUPATEN X
}

\author{
I Made Agus Kurniawan ${ }^{1}$ \\ Ni Made Dwi Ratnadi ${ }^{2}$ \\ A.A.N.B. Dwirandra ${ }^{3}$ \\ ${ }^{1,2,3}$ Fakultas Ekonomi dan Bisnis Universitas Udayana (Unud), Bali, Indonesia \\ 1e-mail: aguskurniawan.ak987@gmail.com
}

\begin{abstract}
ABSTRAK
Penelitian ini bertujuan untuk mengungkap realitas pengelolaan piutang PBB-P2 ditinjau dari penatausahaan, penagihan, dan penghapusan piutang. Eksplorasi pemahaman informan menggunakan fenomenologi sebagai metodologi, dengan paradigma interpretif sebagai pijakan penelitian. Temuan penelitian bahwa penatausahaan piutang terkendala oleh validasi dan pemutakhiran data, manajemen SDM, sarana dan prasarana, penguasaan teknologi, dan kurangnya pemahaman akuntansi. Penagihan piutang PBB-P2 dengan sistem jemput bola, memperluas akses pembayaran, dan menerbitkan surat panggilan bagi penunggak pajak. Penghapusan piutang PBB-P2 dilaksanakan hanya sebatas penyisihan piutang, namun informan memiliki kesadaran bahwa piutang yang telah melewati jangka waktu penagihan seharusnya dihapus.

Kata kunci:Piutang, penatausahaan, penagihan, penghapusan, interpretif, fenomenologi.
\end{abstract}

\begin{abstract}
This study aims to reveal the reality of the PBB-P2 receivables management in terms of administration, billing, and write-off account receivables. Exploration understanding of informants using phenomenology as a methodology, with interpretive paradigm as a foothold research. The study's findings that the administration of accounts receivable is constrained by validation and updating data, human resource management, infrastructure, technology mastery, and a lack of understanding of accounting. Collection of accounts receivable PBB-P2 with the system pick up the ball, extend access to payment, and issuing summons for delinquent taxes. Write-off of receivables carried out only limited allowance, but the informant was aware that the receivables that have passed through the billing period should be removed.

Keywords: Accounts, administration, billing, deletion, interpretive, phenomenology.
\end{abstract}




\section{PENDAHULUAN}

Desentralisasi fiskal bertujuan memberikan kesempatan kepada daerah untuk menggali berbagai sumber dana berdasar kebutuhan daerah, serta secara khusus diatur dalam undang-undang UU No. 25 tahun 1999 jo UU No. 33 tahun 2004tentang perimbangan keuangan antara pusat dan daerah.Manifestasi dari desentralisasi fiskal tersebut adalah terbitnya Undang-Undang Nomor 28 Tahun 2009 tentang pajak daerah dan retribusi daerah.Implementasi Undang-undang tentang otonomi daerah dan desentralisasi fiskal membawa konsekuensi pada kemandirian daerah dalam mengoptimalkan penerimaan daerahnya. Haldenwang(2015) mengungkapkan hal yang sama.

"The overall objectives of the devolution of the land and building tax are to improve revenue autonomy of local governments, to increase sub-national revenues and to reduce local governments' dependence on fiscal transfers from the central government."

Dampak diberlakukannya UU 28/2009 adalah dialihkannya Pajak Bumi dan Bangunan Perdesaan dan Perkotaan (PBB-P2) dari pemerintah pusat kepada pemerintah daerah.Sejak pengalihan kewenangan pengelolaan PBB-P2 bulan Januari 2014, Pemda memiliki kewenangan untuk menentukan besarnya pajak terutang. Kewenangan pemajakan atas tanah dan bangunan merupakan hak dari Pemerintah Daerah, dengan kata lain hak pemajakan PBB-P2 sejatinya berada pada Pemerintah Daerah bukan pada Pemerintah Pusat (Sari, 2010)

Pengalihan tersebut juga menandai bertambahnya tanggung jawab Pemda, seperti penyusunan kebijakan pengelolaan PBB-P2, menyiapkan administrasi seperti pengelolaan tunggakan, pemungutan pajak, penilaian, dan lain-lain. Selain itu diperlukan integrasi terhadap struktur organisasi yang telah ada sebelumnya 
(Kellyet al., 2011).Pengalihan PBB-P2 yang tidak disertai data yang valid dan akurat hanya akan memindahkan masalah ke daerah. Data PBB-P2 yang tidak valid dan akurat tersebut akan mempengaruhi kualitas penyajian laporan keuangan dan mengakibatkan potensi kehilangan penerimaan PBB-P2 (Pendapat BPK, 2015)

Pengelolaan piutang PBB-P2 perlu mempersiapkan peraturan-peraturan sebagai dasar hukum untuk menjamin adanya kepastian dan mengatur jalannya suatu pemerintahan (Nurtanzila dan Kumorotomo, 2015). Tujuannya agar masyarakat memperoleh kepastian, kemanfaatan dan keadilan di dalam kehidupan bernegara dan bermasyarakat (Indrati, 2007).Peneliti memperhatikan selama ini Perda dan Perbup di Kabupaten X yang berkaitan dengan pajak daerah merupakan transplantasi peraturan daerah lain yang terlebih dahulu terbit. Padahal Perda yang diterbitkan oleh Pemda lain sudah pasti tidak akan mencerminkan kehendak dan kondisi dari pada rakyat setempat (Jalaludin, 2011).

Rendahnya kualitas Peraturan Daerah berdampak pada proses pengelolaan PBB-P2, salah satunya adalah proses penagihan. Sistem penagihan PBB yang baik dan dilaksanakan dengan serius berdampak pada pencapaian target penerimaan PBB. Dimana sistem tersebut dapat meningkatkan ketaatan dari penanggung pajak (Kamba, 2013). Pengamatan peneliti terhadap pelaksanaan Perda pajak daerah adalah tidak dilaksanakannya tindakan penagihan pajak terutang yang telah jatuh tempo dengan menerbitkan surat teguran, surat peringatan atau surat lainnya yang sejenis. 
Tidak terlaksanakannya prosedur penagihan di atas berdampak pada jumlah piutang pajak daerah yang membengkak setiap tahun, serta tidak tercapainya target penerimaan PBB-P2(Tabel 1). Besarnya dana yang harus dicadangkan dalam penyisihan piutang tersebut berasal dari penyisihan piutang dari tahun 1998-2015. Hal tersebut memperlihatkan bahwa pembayaran piutang PBB-P2 yang tidak lancar, baik ketika dikelola oleh KPP maupun Dispenda. Dengan target penerimaan PBB-P2 sebesar Rp 17.000.000.000,- untuk tahun 2014 dan 2015 tidak dapat menutupi besarnya penyisihan piutang tersebut(Tabel 2).

\section{Tabel 1.}

Jumlah Piutang Pajak Daerah tahun 2014 dan 2015 (dalam ribuan rupiah)

\begin{tabular}{|c|c|c|c|c|c|c|c|c|c|c|}
\hline \multirow{2}{*}{ NO } & \multirow{2}{*}{$\begin{array}{c}\text { JENIS } \\
\text { PAJAK }\end{array}$} & \multicolumn{3}{|c|}{ PIUTANG } & \multicolumn{4}{|c|}{ PENYISIHAN } & \multicolumn{2}{|c|}{ SALDO AKHIR } \\
\hline & & 2014 & 2015 & $\%$ & 2014 & $\%$ & 2015 & $\%$ & 2014 & 2015 \\
\hline 1 & Hotel & 7.767 .758 & 8.773 .326 & 12,95 & 93.341 & 1,20 & 1.287 .914 & 14,68 & 7.674 .416 & 7.485 .411 \\
\hline 2 & Restoran & 2.106 .846 & 3.918 .730 & 86,00 & 111.066 & 5,27 & 627.510 & 16,01 & 1.995 .780 & 3.291 .220 \\
\hline 3 & Hiburan & 436.069 & 2.291 .117 & 425,40 & & - & 127.754 & 5,58 & 436.069 & 2.163 .363 \\
\hline 4 & Air Tanah & 187.813 & 1.243 .756 & 562,23 & & - & 21.191 & 1,70 & 187.813 & 1.222 .564 \\
\hline 5 & PBB-P2 & 76.748 .366 & 85.746 .640 & 11,72 & 41.429 .161 & 53,98 & 55.367 .956 & 64,57 & 35.319 .205 & 30.378 .684 \\
\hline \multicolumn{2}{|c|}{ JUMLAH } & 87.246.854 & 101.973.572 & 16,88 & 41.633.569 & & 57.432.327 & & 45.613.285 & 44.541.244 \\
\hline
\end{tabular}

Sumber : Dispenda Kabupaten X

Tabel2.

Realisasi Pendapatan PBB-P2 tahun 2014 dan 2015

(dalam rupiah)

\begin{tabular}{cccccc}
\hline No & \multicolumn{1}{c}{ Uraian } & Anggaran & Realisasi & \% & \multicolumn{1}{c}{ Lebih/(Kurang) } \\
\hline 1 & PBB-P2 tahun & 17.000 .000 .000 & 16.241 .745 .807 & 95,53 & $(758.254 .193)$ \\
& 2014 & & & & \\
2 & PBB-P2 tahun & 17.000 .000 .000 & 13.808 .360 .312 & 81,22 & $(3.191 .639 .688)$ \\
& & & & \\
\hline \multicolumn{2}{l}{ 2015 }
\end{tabular}

Berdasarkan uraian di atas maka peneliti ingin mengetahui bagaimana pengelolaan piutang PBB-P2 di Dinas Pendapatan Kabupaten X. Dimana tujuan dari penelitian ini adalah untuk mengungkap, memahami, dan memaknai realitas 
secara mendalam pengelolaan piutang PBB-P2 di Dinas Pendapatan Kabupaten X ditinjau dari penatausahaan, penagihan, dan penghapusan piutang.

Manfaat penelitian ini adalah untuk memberikan gambaran kepada pihak terkait khususnya SKPD Dinas Pendapatan agar lebih memperhatikan program/kegiatan yang sudah dianggap baik, serta sebagai bahan evaluasi terhadap pelaksanaan pengelolaan piutang PBB-P2 yang telah berjalan.Penelitian ini mendukung Theory of Planned Behavior (TPB) yang dapat dipergunakan untuk memprediksi dan meramalkan suatu perilaku yang dipengaruhi oleh niat.

Demi mencapai tujuan penelitian, TPB dipergunakan sebagai landasan teori dalam penelitian ini. Teori ini menyediakan suatu kerangka untuk mempelajari sikap terhadap perilaku. Berdasarkan teori tersebut, penentu terpenting perilaku seseorang adalah intensi untuk berperilaku. Intensi individu untuk menampilkan suatu perilaku adalah kombinasi dari sikap untuk menampilkan perilaku tersebut dan norma subjektif. Sikap individu terhadap perilaku meliputi keyakinanmengenai suatu perilaku, evaluasi hasil perilaku, norma subjektif, keyakinan normatif, dan motivasi untuk patuh.

Menurut Peraturan Daerah Kabupaten X No. 10 Tahun 2011 tentang Pajak Bumi dan Bangunan Perdesaan dan Perkotaan, objek pajak adalah bumi dan/atau bangunan yang dimiliki, dikuasai, dan/atau dimanfaatkan oleh orang pribadi atau badan, kecuali kawasan yang digunakan untuk kegiatan usaha perkebunan, perhutanan dan pertambangan.

Piutang adalah jumlah uang yang wajib dibayar kepada pemerintah daerah dan/atau hak pemerintah daerah yang dapat dinilai dengan uang sebagai akibat 
perjanjian atau akibat lainnya berdasarkan peraturan perundang-undangan atau akibat lainnya yang sah.Agar nilai piutang tetap menggambarkan nilai bersih yang dapat direalisasikan, maka piutang-piutang (sebagian atau seluruhnya) yang diperkirakan tidak tertagih perlu dikeluarkan/disisihkan dari akun piutang. Metode untuk menghitung piutang yang tidak tertagih adalah metode pencadangan/penyisihan piutang tidak tertagih (the allowance method). Secara umum, pengelolaan piutang PBB-P2 oleh Dinas Pendapatan dibagi dalam tiga kelompok, yaitu penatausahaan piutang $\mathrm{PBB}-\mathrm{P} 2$, penagihan piutang $\mathrm{PBB}-\mathrm{P} 2$, dan penghapusan piutang PBB-P2 (Buku Pedoman Pengelolaan PBB-P2, 2014).

Untuk meningkatkan dan mengoptimalkan penerimaan PBB P2, Pemda X tetap menerapkan sistem administrasi perpajakan modern yang selama ini telah digunakan oleh pemerintah pusat yang disebut dengan Sistem Manajemen Informasi Objek Pajak (SISMIOP).Disamping itu dalam upaya mengoptimalkan fungsi-fungsi organisasitelah pula dikembangkan sistem-sistem penunjang SISMIOP lainnya berupa Sistem Informasi Payment Online System (POS), Sistem Informasi Geografis (SIG) dan Pelayanan Informasi Telepon (PIT).

Untuk mengungkap, memahami, dan memaknai fenomena pengelolaan piutang PBB-P2 digunakan pendekatan fenomenologi. Alfred Schutz merupakan orang pertama yang mencoba menjelaskan fenomenologi dalam dunia sosial.Perspektif yang digunakan oleh schutz untuk memahami kesadaran itu dengan konsep intersubyektif. Yang dimaksud dengan dunia intersubyektif ini adalah kehidupan-dunia (life-world) atau dunia kehidupan sehari-hari. (Ritzer dan Goodman, 2007:94). Pendekatan semacam ini memiliki implikasi, tidak hanya 
untuk orang yang kita pelajari, tetapi juga untuk diri kita sendiri yang mempelajari orang lain (Ajiboye, 2012).

\section{METODE PENELITIAN}

Dalam penelitian ini, peneliti menggunakan pendekatan fenomenologi yang bersifat kualitatif, dengan paradigma interpretif sebagai pijakan penelitian. Memilih paradigma harus disesuaikan dengan masalah penelitian yang akan dijawab (Darmayasa \& Aneswari, 2015). Paradigma penelitian perlu disesuaikan dengan tujuan penelitian (Setiawan 2011).Penelitian ini bertujuan untuk mengungkap realitas suatu fenomena dalam konteks sosial secara alamiah dengan mengedepankan proses interaksi komunikasi yang mendalam antara peneliti dan fenomena yang diteliti dalam hal ini pengelolaan piutang PBB-P2 di Dinas Pendapatan Kabupaten X.

Jenis data yang digunakan dalam penelitian ini adalah data gabungan dari data primer dan sekunder. Data primer yang diperoleh langsung dari riset lapangan (field research)melalui hasil wawancara. Metode wawancara yang dilakukan oleh peneliti adalah wawancara mendalam (in depth interview).Untuk mendapatkan data sekunder, peneliti menggunakan studi dokumentasi. Dokumen tersebut didapatkan langsung dari dinas terkait sebagai data pendukung. Informan penelitian diperoleh melalui cara key person karena sebelumnya peneliti sudah memahami informasi awal tentang objek penelitian. Informan dalam penelitian ini terdiri dari pihak fiskus (5 orang) selaku pengelola pajak daerah dan wajib pajak (2 orang) selaku pembayar pajak (tax payer). 
Menurut Sugiyono (2014: 398), dalam penelitian kualitatif yang menjadi instrumen penelitian atau alat penelitian adalah peneliti itu sendiri. Oleh karena itu peneliti sebagai instrumen harus divalidasi seberapa jauh peneliti siap melakukan penelitian yang selanjutnya terjun ke lapangan.

Sebagian besar data yang diperoleh dalam penelitian ini diperoleh dari wawancara, observasi, dan dokumentasi. Kombinasi dari metode tersebut diharapkan dapat menghasilkan data yang lebih akurat dalam menjelaskan bagaimana pengelolaan piutang PBB-P2 pada Dinas Pendapatan Kabupaten X.

Analisis data dalam penelitian ini, diterapkan teknik analisis data dari Miles dan Huberman (1994), yang dibagi menjadi tiga aktifitas, yaitu data reduction, data display, dan conclusion. Dalam penelitian ini dilakukan pengujian dengan uji kredibilitas. Pengujian kredibilitas data penelitian kualitatif dapat dilakukan antara lain dengan, perpanjangan pengamatan, peningkatan ketekunan dalam penelitian, triangulasi, dan menggunakan bahan referensi (Sugiyono, 2014).Selain uji kredibilitas, menurut Spiegelberg (1978) dalam mempertahankan kebenaran penelitian seperti halnya penelitian kuantitatif, penelitian kualitatif juga menuntut adanya validitas dan reliabilitas. Dalam penelitian kualitatif pada umumnya validitas dan reliabilitas dikenal sebagai kepercayaan (trustworthiness) (Morse etal, 2002; Starks dan Trinidad, 2007; Kamayanti, 2016:57-63). Trustworthiness diperoleh dengan verifikasi yang dibangun mulai dari awal penelitian hingga penelitian ini selesai. 


\section{HASIL DAN PEMBAHASAN}

Eksplorasi pemahaman pengelolaan piutang PBB-P2 dilakukan secara mendalam menggunakan Epoche. Epoche adalah suatu proses penundaankeputusan, dimana peneliti menunda keputusan yang berkaitan dengan bias personal informan agar dapat fokus kepada pemahaman yang benar-benar murni dari pengalaman informan.Ada empat tahap dalam analisa fenomenologi. Tahapan pertama adalah pengumpulan data dengan mendeskripsikan fenomena dari hasil wawancara yang telah direkam. Manuskrip wawancara mengidentifikasi dan menjelaskan kualitas dari pengalaman dan kesadaran informan. Tahapan kedua yaitu mengidentifikasi tema yang muncul dari deskripsi pada tahap pertama. Tahapan ketiga adalah pengembangan noema dan noesis. Tahap akhir dalam analisa data fenomenologi adalah mengabstraksikan esensi dari korelasi antara noema dan noesis. Proses abstraksi ini disebut dengan eidetic reduction.

\section{Penatausahaan Piutang PBB-P2.}

Pada bagian ini peneliti ingin mengetahui realitas penatausahaan piutang PBB-P2 yang sepenuhnya bersumber dari wawancara terhadap lima orang informan yaitu, A, B, C, D, dan E yang menjelaskan terkait dengan penatausahaan piutang PBB-P2. Sedangkan hasil wawancara dengan WP (informan F dan G) digunakan untuk mengkonfirmasi pernyataan dari kelima informan diatas.

Informan A selaku pembuat laporan piutang PBB-P2, memahami proses penatausahaan piutang yang terdiri dari pencatatan dan pelaporan. Dimana berdasarkan pemeriksaan BPK terhadap laporan keuangan Dispenda tahun 2014 terjadi koreksi jumlah saldo piutang PBB-P2 pada saat itu. 
"Dari tahun 2015 berdasarkan pemeriksaan BPK.....kan ada saldo piutang. Dari saldo piutang itu saya mulai buat jadi saldo awal 2015. Dari situ setiap bulan dari piutang itu dikurangi penghasilan (penerimaan) setiap bulan, sama dikurangi pembayaran pengecualian itu lo. Yang wajib pajak itu merasa sudah bayar waktu dulu di KPP tapi masih kelihatan nunggak disini, di sistem sekarang. Dengan membawa bukti bayar, kalau ada bukti bahwa dia sudah bayar baru kita ikutin jadi pengurangan piutang. Dari piutang itu kan terus bertambah setiap bulan. Tiap bulan ada ketetapan.....nambah, dikurangi dengan penghasilan sama pembayaran pengecualian. Tiap bulan ada ketetapan. Kan ada proses setiap bulan.....proses mutasi, data baru".

Informan A merasakan terdapat masalah dalam pekerjaannya terkait dengan pelaporan piutang. Masalah tersebut berasal dari data piutang keluaran SISMIOP dengan laporan yang dibuatnya menunjukkan angka yang berbeda. Untuk memeberikan penjelasan terhadap perbedaan tersebut informan A merasakan tekanan yang cukup besar. Tekanan tersebut terutama dirasakan ketika terjadinya pemeriksaan oleh BPK.

"Ruwetnya misalkan kita diminta data di sistem dengan data yang kita punya itu pasti beda. Ruwetnya menjelaskan itu ruwetnya. Tapi saya sudah backup pada saat saya buat laporan ketetapan itu saya print yang memang saat itu NOP itu ditetapkan. Saya akalin dengan seperti itu. Soalnya, lho kok beda mana buktimu kamu netapi sekian, saya sudah ada. Pada saat itu saya ini NOP-NOP ini aja yang ditetapkan. Kalau untuk sekarang misalkan diprint pasti beda lagi NOPnya disini".

Potensi fraud yang timbul dari ketidakakuratan database PBB-P2 adalah terbukanya peluang bagi pihak-pihak tertentu untuk memanfaatkan kondisi tersebut, seperti pemberian keringanan pajak kepada wajib pajak tertentu. Seperti yang diungkapkan oleh informan A, sebagai berikut :

“...Kemudian disini, dulu juga sempat kita pertahankan harus lunasin juga karena itu dah masuk ke piutang kan, mau ga mau kita berusaha nagih. Sekarang ada pejabat yang baru diloloskan, kebijakasanaan pejabat yang baru diloloskan tanpa melunasi tunggakan-tunggakan sebeumnya untuk merubah luasnya agar bayar lebih sedikit, agar bayar sesuai dengan luas tanahnya." 
Permasalahan yang dirasakan oleh informan B adalah tidak siapnya Pemda dalam menerima pengalihan PBB-P2. Hal tersebut disadarinya dengan mengatakan "banyak permasalahan kita hadapi". Permasalahan yang dimaksud adalah kesiapan sarana dan prasarana, antara lain IT sangat lemah dan terbatasnya tenaga. Kemudian, ada ketergantungan terhadap satu orang, dibutuhkan penyegaran dan regenerasi. Oleh sebab itu, diperlukan peningkatan kualitas SDM dengan pelatihan.

“...menurut saya ini perlu dilakukan verifikasi dan validasi data, artinya kebenaran akan adanya piutang tersebut. Karena kita tahu, memang di PBB ini kompleksitas di PBB ini cukup perlu pemikiran. Dalam artian perlu mencari solusi-solusi jalan keluar karena PBB ini bagaimana pun menyangkut ke masyarakat dan penyelesaian harus holistik. Ndak bisa terpisah-pisah. Menurut saya dari melihat kejadian itu saya ingin melakukan verifiksi dan validasi data itu sangat sangat kita butuhkan."

"Betul, itu satu adalah penguasaan teknologi. Alat canggih manusianya tidak canggih sama saja. Manusianya canggih alatnya tidak canggih sama saja. Dua-duanya saya akan dukung, alatnya canggih manusianya juga canggih. Oleh sebab itu penguasaan IT peningkatan SDM itu perlu pelatihan, nah ini belum ada".

Informan C merasakan permasalahan yang sama dengan informan

sebelumnya, dimana permasalahan yang terjadi dalam pengelolaan piutang PBB-

P2 adalah data PBB-P2 yang tidak valid, dan masih banyak ditemukan adanya

piutang semu.

“...kan banyak masyarakat WP terutama yang menyatakan bahwa mereka telah membayar pajak dengan membawa tanda bukti tetapi kelihatan datanya itu masih nunggak. Awalnya dari situ, saya fotocopy bukti tersebut. Dari sana saya lihat ada ketidakvalidan data yang diserahkan KPP pratama ke dispenda. Trus saya kumpulkan semua bukti-bukti masyarakat yang mengumpulkan bukti. Itu jumlahnya ada di dispenda sudah perbulan direkap sama sedahan. Dengan menunjukkan tanda bukti, itu dijumlah nanti dikurangi dengan piutang yang dari KPP itu. Trus yang kedua, sedahan juga keluar mencari WP yang mana saja yang masih.....kan sedahan membawa data yang nunggak. Dicari itu, kenyataan ada memang WP yang benar-benar 
nunggak, tapi ada juga WP yang sudah membayar dengan menunjukkan tanda bukti itu, itu validasinya. Itu untuk piutangnya. Kemudian banyak juga piutang-piutang itu yang semu. Tanah-tanah sudah dijual ke orang lain tapi tanahnya tetap atas nama yang sebelumnya. Berarti yang membeli tidak bisa membayar pajak, karena namanya masih atas nama yang lama. Sedangkan SPPT itu kan dikirim ke WP yang lama, sedangkan WP yang lama sudah menjual tanahnya. Kan otomatis dia tidak mau bayar".

Menurut informan $\mathrm{C}$ masyarakat sebenarnya memiliki kesadaran untuk melaksanakan kewajiban perpajakannya, namun data yang menjadi dasar penentuan pajak terutang tidak sesuai dengan keadaan objek yang sebenarnya, ketidakvalidan data inilah yang mempengaruhi tingkat kesadaran masyarakat. Disamping itu, keterbatasan akses pembayaran merupakan faktor lainnya yang mempengaruhi kesadaran masyarakat.

"Kadang-kadang kesadarannya bukan rendah. Mau dia membayar asalkan SPPTnya itu datanya sesuai dengan kepemilikan tanah. Kesadaran membayar rendah itu karena pembayaran itu sekarang harus ke bank. Itu terutama yang di desa-desa itu agak kesulitan. Memberatkan. Kalau dulu sedahannya langsung ke banjar-banjar mungut. Sedangkan sekarang WP harus datang ke bank untuk membayar. Apalagi yang di payangan, tampaksiring, banknya kan cuma satu BPD itu aja. BPD cuma ada satu di kota kecamatan lagi.....terutama yang di desa-desa yang agak jauh kan males. Itu kendala juga".

Informan D menyatakan permasalahan dalam pengelolaan piutang PBB-P2

adalah database PBB-P2 belum mutakhir, serta data piutang PBB-P2 belum valid dan akurat.

"Semenjak PBB-P2 itu dilimpahkan ke Pemda X mulai januari 2014 itu tentu menjadi tanggung jawab Pemda X untuk mengelola PBB-P2. Baik itu datanya, baik itu piutangnya, baik itu sistemnya kan begitu nike, jadi menjadi tanggung jawab pemda untuk melakukan pengelolaan PBB-P2. Tentu data yang diberikan tersebut dari data yang dilimpahkan itu banyak ada permasalahan-permasalahannya......atas pengalihan PBB-P2 ke Pemkab $\mathrm{X}$. Diantara permasalahan itu salah satunya adalah database PBB-P2 yang diserahkan belum mutakhir. Juga diantaranya adalah data piutang PBB-P2 belum valid dan belum akurat. Atas dua hal permasalahan tersebut tentu 
harus dicarikan solusi-solusinya, upaya-upaya apa yang dilakukan oleh pemda utamanya Dispenda X".

Regulasi yang menjadi dasar pengelolaan PBB-P2 di Kabupaten X saat ini antara lain Perda 10/2011 dan Perbup 27/2013 menurut informan D merupakan hasil copy paste dari Perda dan Perbup Kota Depok. Informan D menemukan banyak kejanggalan di dalamnya.

"Harusnya.....harusnya ada peraturan bupati yang mengatur masalah ini pendaftaran, pendataan dan penilaian.....termasuk penetapannya, udah itu termasuk juga yang tidak ada di perbup kita itu masalah tatacara.....penetapan dan penerbitan SPPT. Itu belum ada. Yang ada di perbup 27 adalah hasil copy paste Depok. Nah.....udah. Depoknya berbunyi lain, disini yang salah ketik."

Permasalahan dalam pengelolaan piutang PBB-P2 yang dihadapi oleh pemda setelah pengalihan adalah tidak validnya data piutang PBB-P2, databse PBB-P2, dan peta. Sehingga diperlukan 3 validasi, yaitu validasi piutang, validasi data, dan validasi peta. Banyak perubahan yang telah terjadi pada objek pajak, seperti misalnya mutasi yang berimbas terhadap berubahnya kepemilikan dan peruntukannya.

"Belum valid, belum valid. Makanya, sebetulnya ada 3 validasi yang dilakukan validasi piutang, validasi data dan validasi peta. Harusnya 3 validasi ini dilakukan. Yang jelas nanti kami merencanakan untuk melakukan 3 validasi. Karena banyak perubahan yang terjadi di peta terutama dari sisi peruntukan, SPP yang tidak, mutasinya tidak dilaporkan. Banyak yang seperti itu".

Dari realitas yang dipaparkan oleh informan berkaitan dengan penatausahaan piutang PBB-P2 di atas, dapat diketahui bahwa permasalahan dalam penatausahaan piutang PBB adalah pertama, validasi dan pemutakhiran data, kedua, lemahnya manajemen SDM, ketiga, kurangnya sarana dan prasarana, 
keempat, rendahnya penguasaan teknologi, dan kelima, kurangnya aturan teknis. Seperti pada Gambar 1.

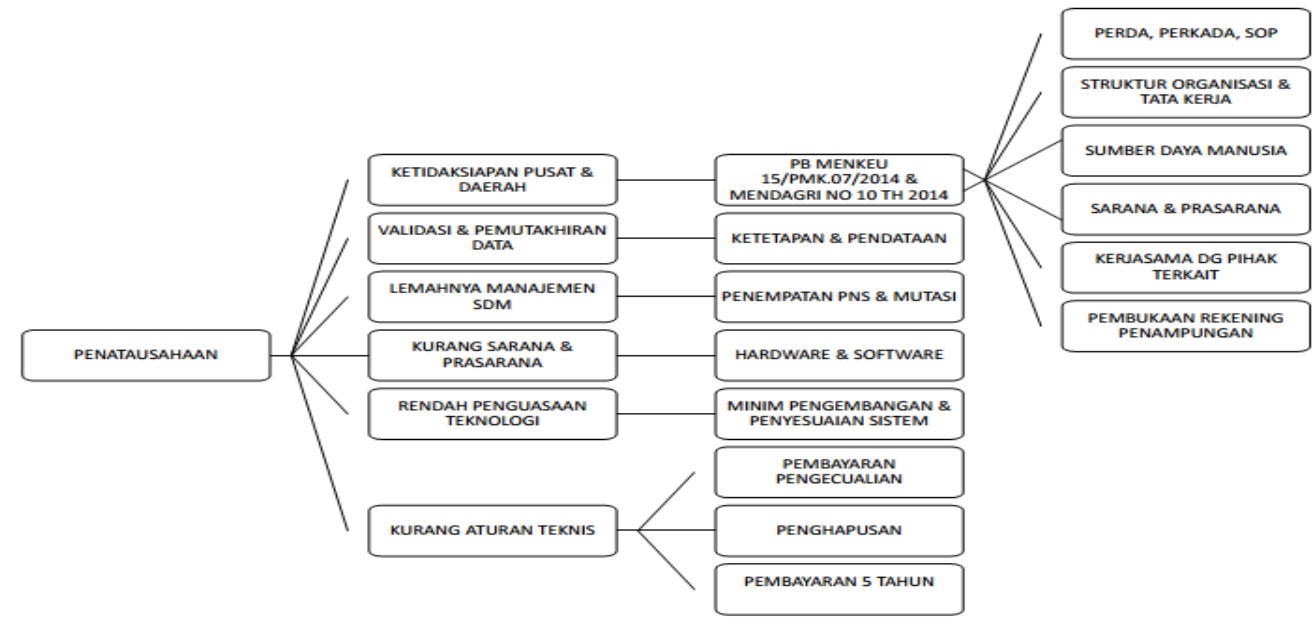

Gambar 1.Realitas Penatausahaan Piutang PBB-P2.

Sumber : hasil wawancara

Selama ini data piutang yang diserahkan oleh pemerintah pusat dalam rangka pengalihan pengelolaan PBB-P2 masih perlu untuk dilakukan validasi serta pemutakhiran. Validasi data piutang dimaksudkan untuk memastikan kebenaran data tersebut. Informasi atas data piutang yang benar dan valid dapat menumbuhkan kepercayaan dan kesadaran WP. Sedangkan pemutakhiran database PBB-P2 diperlukan untuk memastikan kebenaran data objek pajak. Seperti pengalaman yang dirasakan informan G ketika peneliti temui sesaat setelah mengurus administrasi PBB-P2 di Dispenda sebagai berikut :

“Tahun 2012 sudah masuk bangunannya. Padahal bangunan belum ada."

Dari pernyataan informan $\mathrm{G}$ diatas diketahui bahwa database PBB-P2 yang merupakan dasar untuk mencetak SPPT masih terdapat kesalahan. Dimana pada tahun 2012 diatas tanah informan G belum berdiri bangunan namun di SPPT telah tercantum bangunan. Hal ini sangat merugikan bagi wajib pajak dan bukan 
tidak mungkin dapat mempengaruhi tingkat kesadaran mereka dalam membayar pajak.Informasi atas data piutang yang benar dan valid dapat menumbuhkan kepercayaan dan kesadaran WP.

Demi kelancaran proses di atas, merupakan tanggung jawab pemerintah daerah dalam menyediakan SDM yang berkualitas, sarana dan prasarana yang memadai, teknologi informasi, serta aturan teknis sebagai landasan pelaksanaan. Manajemen SDM oleh pemerintah daerah harus ditingkatkan dengan menempatkan PNS sesuai dengan kualifikasi yang dibutuhkan. Setelah SDM terpenuhi maka selanjutnya adalah memperbaiki serta menambah sarana dan prasarana, baik itu berupa perangkat keras maupun perangkat lunak. Dibutuhkan pula penguasaan teknologi, dimana hal tersebut tidak dapat dilakukan secara instan, untuk itu SDM yang telah dipilih perlu ditingkatkan kemampuannya dengan memberikan pelatihan-pelatihan. Sehingga tercipta keseimbangan antara teknologi dan pemakainya.

Ketika dikaitkan dengan TPB maka keyakinan (belief) WP terhadap kebenaran database PBB-P2 dapat mempengaruhi niat (intention) WP dalam membayar pajak, pada akhirnya menimbulkan perilaku yang tidak taat terhadap peraturan perpajakan yang berlaku. Seperti dapat digambarkan pada Gambar 2.

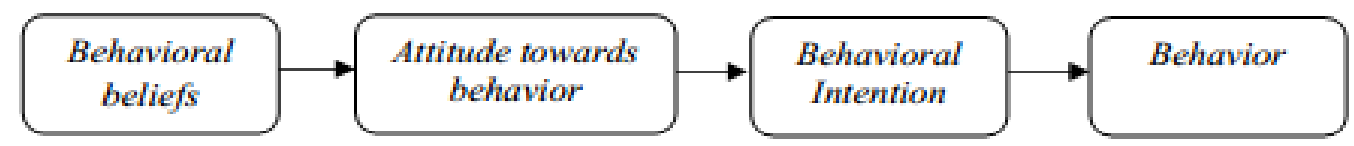

\section{Gambar 2. Proses Terbentuknya Perilaku WP yang Dipengaruhi oleh Behavioral Beliefs}

Sumber : Theory of Planned Behavior (Ajzen, 1988) 


\section{Penagihan Piutang PBB-P2}

Sesuai dengan hasil observasi yang telah dilakukan peneliti menemukan terdapat kebijakan pembayaran PBB-P2 5 tahun terakhir. Dimana sebelumnya WP yang ingin mengurus administrasi PBB-P2 harus melunasi semua hutang pajak sebelumnya. Namun, saat ini WP cukup hanya membayar hutang pajak 5 tahun terakhir saja. Kemudian dari informasi tersebut peneliti bertanya tentang kebijakan yang dilakukan oleh Dispenda $\mathrm{X}$ tentang pembayaran piutang PBB-P2 5 tahun terakhir. "Kebijakan pembayaran dari tahun 2011 mempengaruhi jumlah piutang?”. Informan A menjelaskannya sebagai berikut:

"Mempengaruhi. Pastinya mempengaruhi. Cuma kalau kita tetap nagih kemungkinan ini juga ga akan terbayar karena wajib pajak ga mau. Itu masalahnya. Kalau kita kekeh harus bayar. Dia ga akan mau wajib pajak. jadi ini juga ga dapat ini juga ga dapat. Jadi ini lumayan membantu sih mengurangi piutang. Karena lumayan dia dapat yang gede-gede itu lebih dikit membayar walaupun ga sepenuhnya dia lunas. Cuma sekarang kata ada lagi kebijakan boleh bayar tahun ini aja,tapi tetap kita menagih".

Selanjutnya berkaitan dengan penagihan piutang PBB-P2, informan A menjelaskannya :

"Penagihan lewat kayak gini, print out dia suruh bayar. Kadang gini ngudiang men mayah pajak [untuk apa bayar pajak], len motor kan bisa tarike tanah raga kan sing [kalau motor kan bisa ditarik tanah saya kan tidak] dia punya pikiran seperti itu. Berarti kan belum pernah ada sampai tanahnya diambil gara-gara tidak bayar pajak. Ada sih omongan gitu waktu dulu saya nyebar SPPT. Ah ngujang men tiang mayah pajak masih tanah tiang sing kal mesita [ah untuk apa saya bayar pajak toh juga tanah saya tidak akan disita]. Ada omongan seperti itu. Itu kan belum pernah terjadi dari waktu KPP”.

Informan A menyatakan belum pernah menerbitkan surat teguran terhadap WP yang menunggak, bahkan sejak masih dikelola oleh KPP. 
"Belum pernah. Selama pelimpahan ke kita belum pernah. Masih kita menagih secara.....mencari celah biar dia mau aja dulu bayar dengan cara ini dah, dikasi keringanan dipungut 5 tahun. Lumayan juga. Dulu kan megujeggujegan dini sai [sering ribut-ribut disini]. Setiap orang membayar pasti misi miyegan dini [pasti bertengkar/ribut disini]. Akhirnya diambil kebijakan seperti ini, sudah mereda dia. Maulah dia menerima akhirnya. Ada yang gede pajaknya ga mau bayar karena merasa sudah membayar tapi buktinya hilang. Kita kan ga bisa berbuat apa-apa ini."

Berdasarkan pengalaman informan $\mathrm{B}$, pemungutan langsung yang dilaksanakan saat ini dalam upaya penagihan piutang PBB-P2 adalah efektif sekali. Pemungutan oleh sedahan ini, khususnya bagi WP perdesaan sangat bermanfaat, karena pemahaman menurut informan B selama ini ada keengganan dari WP untuk membayar ke Tempat Pembayaran Elektronik (TPE, misalnya bank, LPD, koperasi) yang tempatnya cukup jauh, perlu antre, dan merasa malu terutama bagi kalangan petani.

"Efektif sekali. Karena saya turun langsung. Minimal informasi tersebut sampai ke masyarakat dan masyarakat tahu kalau pemerintah jemput bola. Melayani mereka, bukan kita yang dilayani. Anda bisa bayar ke LPD, koperasi, bank, atau petugas kita yang mendatangi. Kemarin aja kita baru kita turun 5 putaran hasilnya sudah menggembirakan buat saya pribadi."

Penagihan piutang PBB-P2 menurut informan C dilaksanakan berdasarkan peraturan. Peraturan yang dimaksud tidak khusus mengatur tentang penagihan piutang PBB-P2 saja tetapi peraturan tentang penagihan pajak.

"Kalau peraturan itu bukan penagihan piutang saja, penagihan pajak. Penagihan pajak itu kan termasuk penagihan piutang juga".

Penagihan dapat dilakukan dengan dua cara. Pertama, WP dapat langsung melakukan pembayaran ke bank terdekat. Kedua, WP dapat membayar langsung kepada petugas pungut yang ada di wilayahnya atau dapat juga melakukan pembayarn di LPD. 
"Penagihan pajak itu, satu langsung WP yang langsung membayar ke bank terdekat. Trus yang kedua, sedahan langsung ke lapangan untuk memungut. Atau sedahan langsung menyarankan bisa membayar ke LPD”.

Upaya penagihan yang sudah dilakukan menurut informan D sesuai

dengan Perbup adalah melalui 3 tata cara pemungutan. Tata cara pemungutan yang dimaksud adalah pertama, pemungutan melalui Bank BPD. Kedua, selain di bank pembayaran PBB-P2 diperluas hingga LPD dan koperasi. Ketiga, pemungutan melalui petugas pungut.

"Nah upaya penagihan yang sudah dilakukan, kan ada disana diatur tata pemungutan, ada perda ada peturunannya ada perbup. Perbup yang kita miliki di PBB-P2 adalah baru perbup tentang tata cara pemungutan. Di tata cara pemungutan itu ada 3, satu melalui bank persepsi BPD dengan MOUnya, yang kedua dengan tempat pembayaran elektronik atau yang sekarang kita perluas aksesnya pembayaran melalui LPD, koperasi, KSU atau perorangan. Dan yang ketiga tata cara pemungutannya ada dilakukan oleh petugas pungut. Pemungutan keliling yang kemarin itu. Pungutan yang ke banjar-banjar sesuai dengan wilayahnya secara terjadwal".

Pada wawancara ketiga dengan informan D peneliti mendapatkan data baru bahwa per tanggal 1 Desember 2016 telah dilakukan tindakan penagihan dengan menerbitkan surat panggilan kepada WP yang terlambat dan kurang membayar PBB-P2. Yang menjadai sasarannya adalah WP yang termasuk dalam buku 4 dan buku 5. Dimana WP yang termasuk di dalam buku-buku tersebut adalah WP yang memiliki utang PBB di atas Rp 2.000.000,- (dua juta rupiah). Hal tersebut dilakukan sebagai sarana penyampaian informasi dan sarana komunikasi. Diharapkan setelah menerima surat tersebut WP bersedia hadir ke Kantor Dispenda dan memberikan konfirmasi terkait utang pajak mereka sekaligus malakukan pembayaran.

"Setelah jatuh tempo lewat dari jatuh tempo dilakukan penagihan. Penagihan dengan cara apa? Kan begitu. Dengan cara STPD PBB atau 
bentuk lain yang sejenis. Kalau tunggakan kan berarti dibuat bentuk lain yang sejenis termasuk salah satunya surat ini. Boleh itu."

"...dispenda membuat surat ini kan salah satu bentuk daripada salah satu layanan informasi. Kan masuk diantaranya. Kan gitu ya. Layanan informasi kan ketika WP tidak begitu jelas berapa dia nunggak pajak. dia kan akan proaktif, akan komunikasi."

Pemahaman informan E terhadap penagihan piutang PBB-P2 adalah dengan menurunkan petugas pungut ke banjar-banjar. Upaya ini menurutnya memberikan hasil yang baik.

"Sudah, sudah ke banjar-banjar, sedahan ke banjar. Terjadwal. Minggu lalu aja eh bulan lalu aja dari pungutan sedahan itu aja masuk sekitar 2 M. Dari pungutan ke banjar-banjar. Dan kita tunggu ini lagi. Sekarang kan terus turun, tiap hari turun".

Realitas yang dipaparkan oleh informan menunjukkan bahwa upaya tindakan penagihan yang telah dilakukan adalah pertama, sistem jemput bola, kedua, memperluas akses pembayaran, serta ketiga, memberikan surat panggilan kepada penunggak pajak. Upaya sistem jemput bola perlu dipertahankan untuk memaksimalkan penerimaan PBB-P2. Efektivitas sistem jemput bola tersebut disebabkan adanya kebijakan pembayaran piutang pajak 5 tahun terakhir. Kebijakan tersebut merupakan stimulus bagi WP karena dianggap memberikan keringanan dalam membayar pajak. Namun, disisi lain kebijakan tersebut berdampak pada menurunnya tingkat ketertagihan piutang, terutama piutang dari tahun 1998-2010. Kebijakan yang cukup baik diterima ini tentunya harus dituangkan dalam aturan teknis demi kelancarannya.

Salah satu WP yang peneliti temui ketika mengikuti kegiatan jemput bola tersebut adalah informan F. Menurut beliau upaya jemput bola sangat membantu dalam memperoleh informasi terkait dengan PBB-P2 serta mempermudah akses 
pembayaran bagi beliau yang sudah berumur setengah baya. Sebagaimana pernyataan berikut :

"Mangda uningin tiang manten dumun."

"Nggih, aluhan mangkin."

Perluasan akses pembayaran bekerjasama dengan lembaga keuangan seperti BPD, LPD, Bank Pasar Werdhi Sedana, dan koperasi. Kerjasama tersebut diharapkan dapat memberikan kemudahan bagi WP di perdesaan yang selama ini terkendala oleh jarak dan waktu. Kebijakan perlu disosialisasikan agar masyarakat mengetahui dan dapat memanfaatkan kebijakan tersebut demi kemudahan mereka dalam memenuhi kewajiban perpajakannya. Sosialisasi tersebut saat ini masih kurang, seperti yang dirasakan oleh informan $F$ dan $G$, berikut kutipan wawancaranya:

P : "Berarti pak ten uning yen dados ngangge kitir lama?" ["Berarti bapak tidak tahu kalau bisa menggunakan bukti pembayaran yang lama"]

I : "Nggih tiang ten uning, men mangkin yen wenten mangkin penjelasansapunika tiang kan polih driki kenten." [Iya saya tidak tahu, kalau sekarang ada penjelasan seperti itu tiang dapatkan dari sini".]

I : "Sire dumun nggih sane saking Temon? Leak barak (sedikit emosi) .....amahe pipis tiange.Mayah tiang ditu ten ada kemu pise. Polih kertas kebesan sekadi mayah karcis parkir." ["Siapa dulu yang dari Temon? Leak merah (ungkapan emosi).....dimakan uang saya. Bayar saya disana tapi uangnya tidak disetor. Dapat sobekan seperti karcis parkir.”]

P : "Berarti bapak ten uning bahwa nike [berarti bapak tidak tahu bahwa itu] sudah pindah ke daerah?"

I : "Ten, itu belum. Tadi kan tiang mau ngecek niki, kude je mayah, be mekelo ten ngecek."["tidak, itu belum. Tadi kan saya mau ngecek ini, berapa bayar, sudah lama tidak ngecek."]

I : "Ngidang LPD mayah?" ["Bisa di LPD bayar?"]

I : "Nah mungkin karena tiang tumben mayah ten tawang masih. Yang jelas sing tawang tiang." ["Nah mungkin karena saya tumben bayar tidak tahu juga. Yang jelas saya tidak tahu.’] 
Penerbitan surat panggilan bagi WP yang terlambat atau kurang membayar PBB-P2 baru dilaksanakan pada awal bulan Desember 2016. Upaya tersebut penting untuk menunjukkan adanya penegakan peraturan di bidang perpajakan yang selama ini masih berjalan lambat, serta sebagai sarana komunikasi antara pemerintah dengan WP. Untuk itu, peran data sangat penting agar informasi yang disampaikan kepada WP melalui surat himbauan tersebut dapat menggambarkan besarnya utang PBB yang merupakan kewajiban mereka. Sehingga diharapkan WP dapat mempersiapkan rencana pembayaran sedari dini.

Upaya-upaya penagihan tersebut tentu harus didukung dengan regulasi yang jelas, lengkap dengan aturan teknisnya. Setelah semua perangkat yang dibutuhkan lengkap, selanjutnya adalah melaksanakan sosialisasi kepada masyarakat.

Upaya-upaya penagihan tersebut tentu harus didukung dengan regulasi yang jelas, lengkap dengan aturan teknisnya. Setelah semua perangkat yang dibutuhkan lengkap, selanjutnya adalah melaksanakan sosialisasi kepada masyarakat. Penerapan reward and punnishment juga sangat penting dalam meningkatkan keyakinan masyarakat (normative beliefs) sehingga dapat membentuk niat dan perilaku taat pajak dari masyarakat. Hal ini sesuai dengan TPB dimana normative beliefs mempengaruhi terbentuknya subjective norm, yang selanjutnya membentuk behavioral intentionuntuk berperilaku sesuai dengan

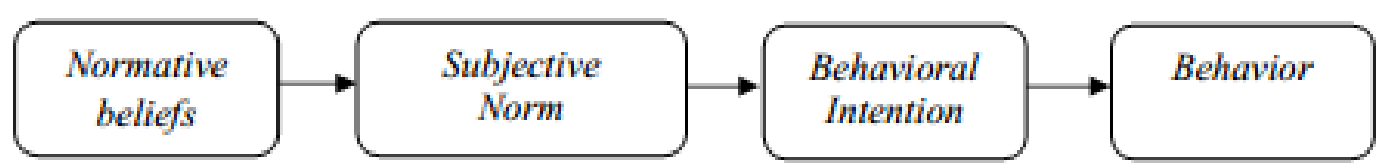


peraturan yang berlaku. Seperti terlihat pada Gambar 3.

\section{Gambar 3. Proses Terbentunya Perilaku Fiskus yang Dipengaruhi oleh Normative Beliefs}

Sumber: Theory of Planned Behavior (Ajzen, 1988)

\section{Penghapusan Piutang PBB-P2}

Menurut informan A sulit untuk melakukan penghapusan piutang karena belum ada jalur pasti (aturan yang jelas), diperlukan proses panjang dan koordinasi dengan pemerintah pusat. Pemerintah pusat yang dimaksud dalam hal ini adalah Departemen Keuangan. Selain itu diperlukan koordinasi dengan KPP yang sebelumnya mengelola PBB-P2.

"Kalau ngapus.....kayaknya susah ya. Jalur pastinya untuk PBB-P2 ini belum pernah ada sampai seperti itu. Makanya juga harus ngobrol sama pusat.....kalau memang berencana menghapus".

Piutang PBB-P2 yang harus dihapuskan menurut informan B adalah piutang yang telah melewati batas daluwarsa pajak, objek yang tidak jelas, dan atas SPPT ganda. Yang terpenting adalah pemda segera menerbitkan kebijakan/peraturan tentang penghapusan piutang tersebut.

"Menurut saya piutang yang sudah kadaluwarsa yang tidak mungkin kita tagih, objek yang tidak jelas, SPPT ganda ya kita harus hapuskan. Sangat penting sekali. Nanti bupati harus menerbitkan suatu kebijakan tentang penghapusan piutang PBB-P2”.

Sama dengan apa yang dirasakan oleh informan A, menurut informan C penghapusan piutang PBB-P2 harus memenuhi banyak persyaratan.

"Sebenarnya dari dulu saya sudah berkeinginan untuk itu. Tapi untuk penghapusan luar biasa syaratnya. Saya sudah dapat konsultasi ke KPP. KPP pun belum berani waktu masih menangani itu. Untuk penghapusan itu". 
"Menurut KPP perjalannya panjang sekali. Begitu saja katanya. Karena masalah ke pusat. Seluruh indonesia belum ada penghapusan".

Menurut Informan D regulasi yang jelas tentang penghapusan piutang belum ada, sehingga sampai saat ini Pemda $\mathrm{X}$ belum menerbitkan Perbup penghapusan piutang.

"Nah itu perbupnya belum ada. Dan.....peraturan bupati tentang tatacara penghapusan piutang belum ada. Rencananya tahun 2017 akan dibuatkan perbup, dan itu ada bidang yang menangani tentang.....di kasi hukum dan perundang-undangan, kita bahannya".

Sama halnya dengan pendapat informan $\mathrm{D}$, penghapusan piutang belum dapat dilaksanakan karena belum ada regulasi dan kebijakannya. Untuk piutang yang melampaui daluwarsa pajak 5 tahun tetap disarankan kepada masyarakat untuk membayar.

"Sementara belum, kita masih menunggu regulasinya untuk penghapusan piutang yang melampaui 5 tahun. Tetapi kalau sekarang belum ada kebijakan. Tetap kita sarankan masyarakat untuk bayar".

Realitas yang diperoleh berdasarkan hasil wawancara dengan informan adalah bahwa metode penghapusan piutang PBB-P2 yang dilaksanakan selama ini hanya sebatas penyisihan piutang. Meskipun penghapusan piutang PBB-P2 hanya dilakukan melalui metode penyisihan piutang, namun pada dasarnya informan menyadari pentingnya penghapusan piutang tersebut untuk menghindari penumpukan piutang, serta memberikan informasi yang benar tentang kondisi piutang PBB-P2 yang sesungguhnya. Penyebab utama piutang PBB-P2 sampai saat ini belum bisa dihapuskan adalah belum adanya regulasi yang mengatur secara rinci mengenai penghapusan piutang tersebut. Rendahnya pemahaman akuntansi pengelola seputar akuntansi piutang mempengaruhi pula belum adanya 
kebijakan akuntansi yang tegas tentang penghapusan piutang. Selain itu, sebelum piutang dapat dihapus haruslah telah dilakukan seluruh tahapan dalam tindakan penagihan terlebih dahulu.

Upaya berupa koordinasi dengan perwakilan pemerintah pusat seperti BPK, KPP Pratama telah dilakukan, namun belum menunjukkan titik terang. Dalam hal ini kontrol perilaku dimana kesulitan yang dirasakan SKPD dalam merealisasikan upaya penghapusan piutang PBB-P2 dapat mempengaruhi niat untuk melakukan upaya tersebut. Hal ini sesuai dengan apa yang dijabarkan oleh TPB, dimana control beliefs (dukungan atau hambatan) dalam proses penghapusan piutang PBB-P2 mempengaruhi percieved behavioral control tergantung pada percieved power yang diterima. Kemudian hal tersebut dapat membentuk behavioral intention seseorang untuk berperilaku sesuai dengan percieved power yang diterima tersebut, yang pada akhirnya membentuk perilaku pengelola dalam menindaklanjuti penghapusan piutang PBB-P2. Seperti yang terlihat pada Gambar 4.

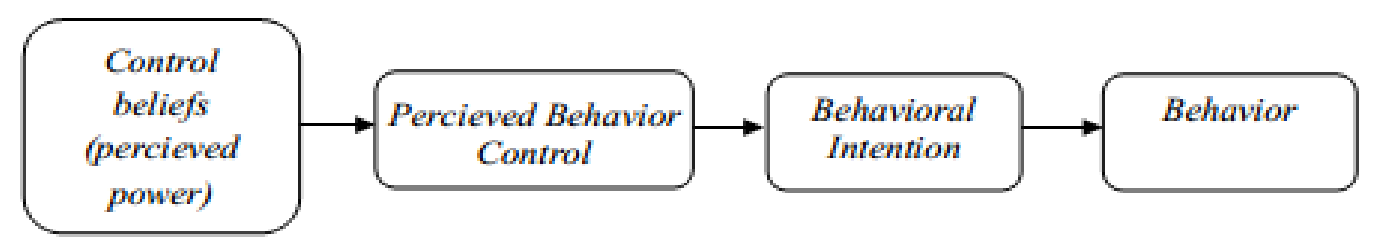

\section{Gambar 4. Proses Terbentuknya Perilaku Fiskus yang Dipengaruhi oleh Control Beliefs}

Sumber: Theory of Planned Behavior (Ajzen, 1988)

\section{SIMPULAN DAN SARAN}

Berdasarkan hasil analisis penelitian yang telah diuraikan di atas, maka selanjutnya dapat disimpulkan mengenai realitas pelaksanaan pengelolaan piutang 
PBB-P2 di Kabupaten X meliputi penatausahaan, penagihan, dan penghapusan. Penatausahaan piutang terkendala oleh data yang dimiliki oleh Dispenda Kabupaten X saat ini. Validasi dan pemutakhiran data PBB-P2 merupakan awal permasalahan. Selanjutnya manajemen SDM yang belum berjalan dengan baik menyebabkan fungsi-fungsi dalam pengelolaan PBB-P2 tidak berjalan lancar. Sarana dan prasarana perlu ditingkatkan guna menunjang pelaksanaan pengelolaan PBB-P2. Ketika Pemda memutuskan tetap menggunakan SISMIOP sebagai sistem untuk mengelola data PBB-P2, dibutuhkan penguasaan teknologi untuk mengimbangi kecanggihan sistem.

Penagihan piutang PBB-P2 dilaksanakan dengan sistem jemput bola, memperluas akses pembayaran, dan menerbitkan surat panggilan bagi penunggak pajak. Sistem jemput bola cukup efektif diterapkan terutama bagi WP yang berada di perdesaan yang selama ini tidak terjangkau oleh pemerintah. Perluasan jangkauan pembayaran bekerjasama dengan BPD, LPD, Bank Pasar Werdhi Sedana, dan Koperasi. Bagi WP yang menunggak diterbitkan surat panggilan sebagai sarana penyebaran informasi dan komunikasi.

Meskipun upaya penyisihan piutang PBB-P2 telah dilakukan, namun informan memiliki kesadaran bahwa piutang yang telah melewati jangka waktu penagihan seharusnya dihapuskan. Penghapusan piutang PBB-P2 terkendala regulasi/ aturan teknis penghapusan piutang. Selain itu, pelaksanaan penagihan pajak yang belum optimal menyebabkan penghapusan piutang belum dapat dilaksanakan. 
Secara umum perilaku pengelola PBB-P2 dipengaruhi oleh norma subjektif. Norma subjektif berupa regulasi/peraturan yang menyediakan petunjuk tentang apa yang seharusnya pantas/tepat untuk dilakukan. Norma inilah yang membentuk niat berperilaku. Perilaku selain ditentukan oleh niat juga dipengaruhi oleh motif. Motif akan harapan masa depan yang lebih baik, serta motif yang disebabkan oleh pengalaman masa lalu ikut membentuk perilaku seseorang.

Dari uarian diatas maka dalam rangka pelaksanaan pengelolaan piutang PBB-P2 dapat peneliti sarankan sebagai berikut :

a) Diharapkan agar pemerintah daerah rutin melaksanakan evaluasi, sehingga kegiatan yang efektif dalam menunjang pengelolaan PBB-P2 dapat dipertahankan dan dilanjutkan bahkan disempurnakan. Seperti misalnya sistem jemput bola dan perluasan akses pembayaran.

b) Mengoptimalkan kegiatan pendataan guna meningkatkan akurasi data PBBP2, serta memaksimalkan tindakan penagihan sesuai dengan peraturan yang berlaku.

c) Pelayanan PBB dan BPHTB punya peluang untuk dapat disimultankan agar setiap terjadi peralihan hak atas tanah dan/atau bangunan khususnya peralihan akibat jual beli tanah dapat dideteksi secara dini melalui proses pelayanan BPHTB.

d) Dukungan kepala daerah berupa peraturan-peraturan, sarana prasarana, anggaran, SDM, serta penyempurnaan terhadap SISMIOP.

e) Memberikan pelatihan serta merekrut PNS yang memiliki kualifikasi yang sesuai dengan kebutuhan dalam pengelolaan PBB-P2. 


\section{KETERBATASAN PENELITIAN}

Penelitian ini dibatasi oleh tiga dimensi pengelolaan piutang, yaitu penatausahaan, penagihan, dan penghapusan piutang PBB-P2.

\section{REFERENSI}

Ajiboye, Emmanuel Olanrewaju. 2012. Social Phenomenologi of Alfred Schutz and the Development of African Sociology. British Journal of Arts and Social Sciences, 4 (1) : 12-25.

Badan Pemeriksa Keuangan Republik Indonesia. 2015. Pendapat BPK.

Darmayasa, N., Aneswari Y.R. 2015. Paradigma Interpretif pada Penelitian Akuntansi Indonesia. Jurnal Akuntansi Multiparadigma. 6 (3) : 341-511.

Haldenwang, C. V. 2015. The Devolution of the Land and Building Tax in Indonesia. Studies. The German Development Institute.

Indrati, M. F. 2007.Ilmu Perundang-Undangan: Proses dan Teknik Pembentukannya. Kanisius. Yogyakarta.

Jalaluddin. 2011. Hakikat dan Fungsi Peraturan Perundang-Undangan Sebagai Batu Uji Kritis Terhadap Gagasan Pembentukan Perda Yang Baik. Aktualita, 6 (3):1-19.

Kamayanti, A. 2016. Metodelogi Penelitian Kualitatif Akuntansi: Pengantar Religiositas Keilmuan. Jakarta: Yayasan Rumah Peneleh.

Kamba, Mochammad Eko S., Saerang, David PE., Pusung, Rudy J. 2013. Evaluasi Pelaksanaan Sistem Penagihan Pajak Bumi dan Bangunan di Kantor Pelayanan Pajak Pratama Bitung. Jurnal Riset Akuntansi Going Concern FEB UNSRAT. 104-114.

Kelly, Roy. 2004. Property Tax Reform in Indonesia: Emerging Challenges from Decentralisation. The Asia Pacific Journal Of Public Administration, 26 (1):71-90.

Miles, Mathew. B., Huberman, A. Michael. 1994. Qualitative Data Analysis : an expanden sourcebook 2nd editions. SAGE Publications, Inc. 
Morse, J.M., Barrett, M., Mayan, M., Olson, K., dan Spiers, J. 2002. Verification Strategies for Establishing Reliability and Validity in Qualitative Research. International Journal of Qualitative Methods, 1 (2) : 13-22.

Nurtanzila, L., dan Kumorotomo, W. 2015. Faktor-Faktor yang Memengaruhi Penerimaan PBB P2 di Kota Yogyakarta Pasca Pelimpahan Kewenangan Pengelolaan PBB P2 oleh Pusat Kepada Daerah. Jurnal Kebijakan \& Administrasi Publik, 19 (2) : 157-169.

Pemerintah Daerah Kabupaten X. 2011. Peraturan Daerah Kabupaten X Nomor 10 Tahun 2011 tentang Pajak Bumi dan Bangunan Perdesaan dan Perkotaan.

. 2013. Peraturan Bupati X Nomor 27Tahun 2013 tentang Tata Cara Pemungutan Pajak Bumi dan BangunanPerdesaan dan Perkotaan di Kabupaten X.

. 2015. Peraturan Bupati X Nomor 67Tahun 2015 tentang Kebijakan Akuntansi Kabupaten X.

Pemerintah Republik Indonesia. 2009. Undang-Undang Nomor 28 Tahun 2009 tentang Pajak Daerah dan Retribusi Daerah. Jakarta.

- 2004. Undang-Undang Nomor $33 \quad$ Tahun 2004 tentang Perimabangan Keuangan antara Pemerintah Pusat dan Pemerintah Daerah. Jakarta.

Sari, Yulia Anggara. 2010. Analisis Efektifitas dan Kontribusi Penerimaan Pajak Bumi dan Bangunan Terhadap Pendapatan Daerah di Kota Bandung. Jurnal Wacana Kerja, Vol. 13, No.2:173-185.

Setiawan, A, Saryono. 2011. Metodologi Penelitian Kebidanan DIII, DIV, SI dan S2. Yogyakarta: Nuha Medika.

Spiegelberg, H. 1978. The phenomenological movement: A historical introduction. The hague: Matinus Nijhoff.

Starks, H., dan Trinidad, S.B. 2007. Choose Your Method: A Comparison of Phenomenology, Discourse Analysis, and Grounded Theory. Qualitative Health Research, Vol.17 No.10. p. 372-1380

Sugiyono. 2014. Metode Penelitian Bisnis (Pendekatan Kuantitatif, Kualitatif dan $R \& D)$. Bandung: Alfabeta. 